\title{
THE CELEBRATION OF NATIVITY: "BROAD-AXE POEM"1
}

DOROTHY M-T. GREGORY

WHITMAN OFTEN USES the word "nativity" as a synonym for "native endowment," or personal qualities. But, of course, the word also means: birth, birthplace (in a context such as "of American nativity") and, in art, the combined representation of Mother and Child. In referring to "Broad-Axe Poem" as the celebration of nativity, I am using the term in this multiple meaning. The opening verses offer one of the most striking symbolic descriptions of birth; the three concluding stanzas are, in turn, a celebration of maternity, of the poet himself, ${ }^{2}$ and of the "shapes" of America as his vision discerns them. Moreover, a whole section in the middle of the poem extols personal qualities.

The synthesizing force and central symbol of the poem is the broad axe, which is dramatically introduced in the first stanza:

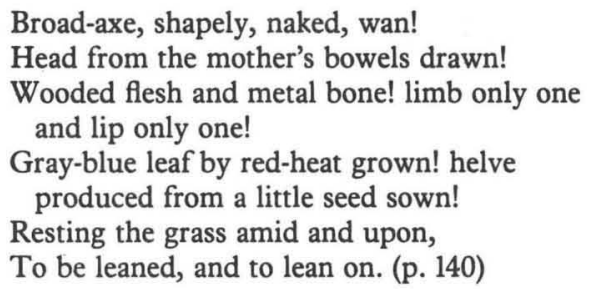

While the axe is presented in its basic function, that of an instrument used both to build and to destroy, the imagery surrounding it makes of the axe, at the same time, both an infant-Hercules emerging out of the mother's womb and a powerful phallus. Words like "wan" and "gray-blue," apt descriptions of an infant "drawn" (note the implicit violence of the word) out of the mother's womb, qualify somewhat the power of the axe. After all, it is only after the gray ore and its wooden handle are joined together that the axe can become a powerful weapon; similarly, it is after care and nurture that an infant, however potentially strong, can assert its power. The last two lines of the stanza express interdependence between the earth and the axe, on the one hand, and (through the associations that the preceding imagery evokes) between the mother and the child, on the other.

But, as I have already suggested, it is not only birth that is celebrated along with the construction of the axe. The description of the forging of the gray ore and of the seed that produced the wooden helve serves also as a 
metaphor for the child's moment of conception: "gray-blue leaf from red-heat grown! helve produced from a little seed sown!" Through this very imagery, the axe becomes not only the product but also the instrument of that conception. In other words, the axe, drawn out of the mother's bowels, is not only the emerging infant but also the phallus of the father. Moreover, in the multiplicity of meanings that a symbol embodies, the axe may well be functioning as the agent of the infant's destructive impulses and sadistic fantasies which, as we learn from Melanie Klein, "are operative at a very early stage of development." 3

This confluence of meanings in the axe in this extraordinary stanza is reinforced by its meter. It has already been noted by several critics that Whitman is loosely employing rhyming trochaic tetrameters, a very unusual occurrence in his versification. ${ }^{4}$ The fact that the rest of the poem continues in free verse makes the first stanza even more striking. I think that Frederik Schyberg's observation that the rhythmic beat of the stanza reproduces the "harsh music of the axe stroke" is apt indeed. But I also believe that just as the imagery of the stanza fuses many meanings, its rhythm orchestrates many beats. Along with the chopping of the axe we can also hear the rhythmic motion of sexual intercourse and the heart-beat of a new-born infant.

That it is, in fact, in such organic "beats" that the meter of the stanza originated becomes apparent if we compare the opening stanza of the poem to an earlier fragment, which makes no mention of the axe but uses the same meter and, for the most part, the same phraseology:

\section{The irregular tapping of rain off my house- eaves at night after the storm has lulled, Gray-blue sprout so hardened grown Head from the mother's bowels drawn Body shapely naked and wan Fibre produced from a little seed sown. ${ }^{5}$}

In pointing out the similarity of this early fragment to the opening stanza of "Broad-Axe Poem," Gay Wilson Allen has remarked that the difference in subject matter between the two indicates that in the case of the latter, the rhythm "did not grow from within but was adapted-not however, inappropriately." It seems to me that such an observation is justified only if by "subject matter" we refer to the literal content of the two stanzas and not to the dynamic one as well. The dynamic connection between the axe and "the sprout so hardened grown" of the earlier fragment is clear in that they symbolically stand for both a new-born infant and a phallus. Therefore, the organic relation between the rhythm of the stanza and its content applies equally to both symbols. The earlier symbol, however, was less successful because it lacked the rhythmic potential of the axe. The "tapping of the rain" (which, as the fragment suggests, must have served an initial parallel in 
nature for the organic rhythms that Whitman wanted to convey) was not an altogether felicitous choice because it did not make the rhythm an integral part of the central symbol. Moreover, the sprout lacked the broader range of symbolic possibilities of the axe. ${ }^{7}$

When Whitman's imagination hit upon the axe as a subject for a poem, he apparently found a perfect symbol in which to express both the universe of his infancy (an unconscious intention, most likely) and the pioneer venture of his country. ${ }^{8}$ It must have been the use of the axe as an instrument of both construction and destruction (building a new world and clearing the wilderness) that made the axe for Whitman, as we find in his notes, the appropriate "American emblem, preferent to the eagle." And may not his preference also reflect his insight into the aggressiveness of the American, an insight that D. H. Lawrence expressed in these words: "The essential American soul is hard, isolate, stoic and a killer"? 10

"Broad-Axe Poem," then, is a fusion of personal and national concerns. In the first stanza the personal element is paramount; in the ones that follow, aspirations for America predominate. After the dramatic introduction of the axe, which, in the second stanza, the poet characteristically calls "an emblem," he sets out to pay tribute to it in the rest of the poem by presenting the "long varied train" of the axe. This long train can be divided in three parts. The first part (stanzas 3 and 4 ) and the third (stanza 15 to the end of the poem) are long pictorial divisions, descriptive pageants of people, events and objects; the intervening section (stanzas 5 to 14 ) is a discursive interlude that celebrates personality.

The first division includes all the lands of the earth, fertile ones such as "lands of pine and oak . . . lands of the lemon and the fig" as well as lands of "rugged ores . . . lands of the make of the axe." Then the geographical representation becomes more localized as a "sylvan hut" with a space "cleared for a garden" suggests an American rural landscape, which, through the associations of the poet, takes us to those who sought "a new England" and found "a new city." It is the settlements resulting from this initial venture and, particularly, the "adventurous and daring persons" who built them and populate them, that occupy the most important place in the first division. The train is now animated with the users of the axe in their various activities, "the butcher in the slaughter house ... the house builder at work in cities or anywhere ... the constructor of wharves ... the city fireman," who uses his axe in an immediately destructive way but with an ultimately constructive purpose: to avert the spread of fire.

This lively procession of the present users of the axe is followed next by "the shadow processions of the portraits of past users." But while we also see among these portraits the "primal patient mechanics and engineers" of famous ancient monuments, we are mainly presented with images of "the antique European warrior with his axe in combat." In the portrayal of the past, 
the destructive acts of the axe are emphasized more than its constructive potential, and the division ends with "mercenaries and bigots" sacking an "old city." (The poet's notes indicate that he had in mind the destruction of Rome in 1527. $)^{11}$

Undoubtedly, Whitman's purpose in juxtaposing the primarily constructive activities of the "new city" to the destruction of the "old city" aims at underscoring his belief that the new world that the United States was building was superior to past civilizations. But in juxtaposing construction and destruction, the poet also stresses the ambiguity of his central symbol, its constructive and destructive potential. As the first division of the train fades away, he calls "the just or unjust" activities of the axe "executive deeds," by which he means manifestations of its essence, and equates them with "the power of personality, just or unjust."

We can understand better what Whitman has in mind if we turn to the following lines from "Poem of Many in One."

\footnotetext{
What we are WE ARE-nativity is answer enough to objections;

We wield ourselves as a weapon is wielded, We are powerful and tremendous in ourselves, We are executive in ourselves ... (p. 180, stanza 2)
}

Powerful personalities then -and here, as usual, the poet speaks primarily of himself-are "executive." Like the axe, they "wield" themselves into action. Self-expression rather than the results of their actions is their primary motivation: "nativity is answer enough to objections."

This comparison of the executive deeds of the axe, whether just or unjust, with the power of personality, "just or unjust," makes the discursive interlude that follows the first division of the train an important part of the poem and not simply an intermission between acts. That is to say, although the axe is not mentioned even once in the interlude, this passage relates to the powerful symbol in the sense that the personal qualities it celebratesqualities that are undefined because they vary from individual to individual-achieve importance only if they are expressed through action, through "executive deeds."

Executive deeds of great individuals are indeed the essence of the poet's "greatest city," no doubt a visionary development of the "new city" founded by the forefathers. In such a city, "outside authority enters always after the precedence of inside authority." This statement both resembles and differs from the one in which the power of personality, whether just or unjust, was extolled. Both statements strongly advocate individualism. The earlier one, however, seemed to give license to aggressive energies as well for their own sake. By contrast, the latter sounds more like an affirmation of the Quaker 
trust in the "inner light," which implies that inner authority is enlightened rather than arbitrary. ${ }^{12}$

It appears that Whitman is attempting in this interlude to blend contradictions of personality, conflicting qualities: the aggressive energies usually associated with masculinity and the pacifist spirit of the Quakers, which allows room for the gentler qualities that seem to be associated in his mind with femininity. This assocation was probably reinforced by the fact that his own mother (the mother of "mild words" in "There Was a Child Went Forth") had been brought up by a Quaker mother. ${ }^{13}$

In locating the place where the greatest city stands, Whitman does not use either geographic boundaries or impressive landmarks; he merely enumerates characteristics relating to behavior - "the finest of the fine arts"-and it is clear that many of these characteristics reveal Quaker attitudes:

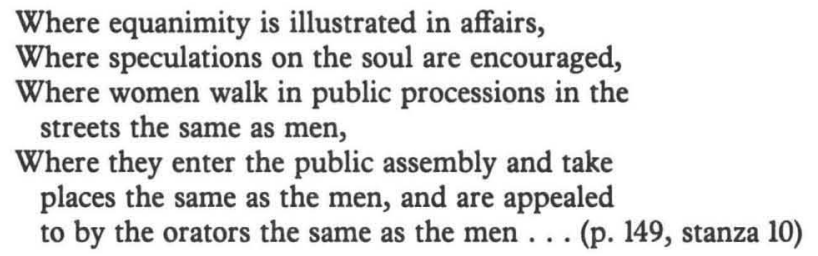

Of the above lines, those that refer to men and women strike us as a radical pronouncement on sexual egalitarianism for Whitman's time. To Quakers, however, such a statement would not have sounded unfamiliar if we consider the fact that they already allowed women to become ministers in their society. Undoubtedly, the Quaker values of Whitman's home provided him with the right soil for the growth of a stance that favored the equality of the sexes. ${ }^{14}$

In further envisioning "the greatest city," the ideal outcome of the States, the poet thinks again of both man and woman:

All waits, or goes by default, till a strong
being appears;
A strong being is the proof of the race, and
of the ability of the universe,
When he or she appears, materials are overawed,
The dispute of the soul stops,
The old customs and phrases are confronted,
turned back, or laid away. (pp. 149-150, stanza 12)

It is the second division of the train of the Broad Axe that will realize the poet's dream. But as subsequent analysis will demonstrate, the seed of the androgynous vision of this stanza is to be found in a still more private domain than the nurturing soil of Quakerism. This private domain appears to be the 
symbiotic mother-son relationship of infancy, a configuration of "nativity" in its meaning of the combined representation of mother and child. ${ }^{15}$

The second division of the train (starting with stanza 15) opens with a single landscape, very different in its barren surface from the fertile woodlands that formed the opening of the first division. But with all its "forbidding appearance," the "sterile landscape" occupies this unique place in the pageant because it covers the precious ore. We are, in fact, witnessing a ritual: the mining and forging of the axe. But the imagery associated with this ritual does not reveal the psychosexual origins of the symbol. The axe here is neither infant nor phallus but the symbolic instrument of the constructive and destructive "executive deeds" of civilization.

Those that the axe "has served" enter the procession now in a chronological order that reverses the order of the first division. There, we started with the present users of the axe, the descendants of the "new city" of the Pilgrim Fathers, and ended with the destructive pillagers of the "old city." Here we start with ancient civilizations and move gradually to the present. In both cases, the contrast aims at bringing out the superiority of the civilization of the poet's country. After some of the representatives of these ancient civilizations fade away, the poet's commentary intervenes again to remind the reader that the axe has served all these men both in "the making of helms for the galleys of pleasure and the making of those of war," stressing once again both the constructive and destructive aspects of the axe. This reminder is timely indeed because the next figure that enters the procession is an awesome one.

Leaning on "a ponderous axe," enters the European headsman who, carrying out the will of powerful leaders - just or unjust - has beheaded "rejected kings" and "uncrowned ladies," "rivals, traitors ... and the rest." Terrible though, the poet admits, this activity of the axe has been, it has played a part in the gradual struggle of European civilizations toward "the good cause," the creation of a world where the rights of individuals count. This world, first conceived in Europe, will be brought to full fruition in America. As the headsman withdraws from the scene, his role no longer necessary, the bloody weapon is washed away and is transformed into "the mighty and friendly emblem of the power" of the poet's own race, "the newest largest race." It is this new axe that "leaps" across the Atlantic ${ }^{16}$ to clear away the "solid forest" and set the foundations of a new civilization. The axe now becomes both the shaper and the inclusive symbol of many other constructive instruments, the "hoe, rake, pitch-fork, pencil, wagon, staff, saw, jackplane, mallet, wedge, rounce."

The train of the axe is again resumed, this time formed entirely by "shapes of the using of axes" in America and their "users." Every subdivision is announced with the trumpet-like refrain, "the shapes arise!" The shapes include "dwellers in cabins" as far west as California, as far north as Minnesota, 
as far south as the Rio Grande. They include complex structures such as factories and arsenals, shipyards and ships, but also simple wooden objects that serve the basic needs of the life-cycle: the babe's cradle, the planks of the family home, the coffin of the dead. And to make it clear that the "greatest city" is still an unrealized ideal, the shapes include prisoners, adulterers, convicted murderers. The procession continues juxtaposing objects and people until we reach the most important part of the train (the last three stanzas of the poem).

The solitary woman who now enters the procession differs from those who preceded her in that she bears no resemblance to ordinary humanity. Her poise, omniscience and purity make of her some kind of Goddess Athena in combination with Virgin Mary. But she is more than that. She is "a law of nature."

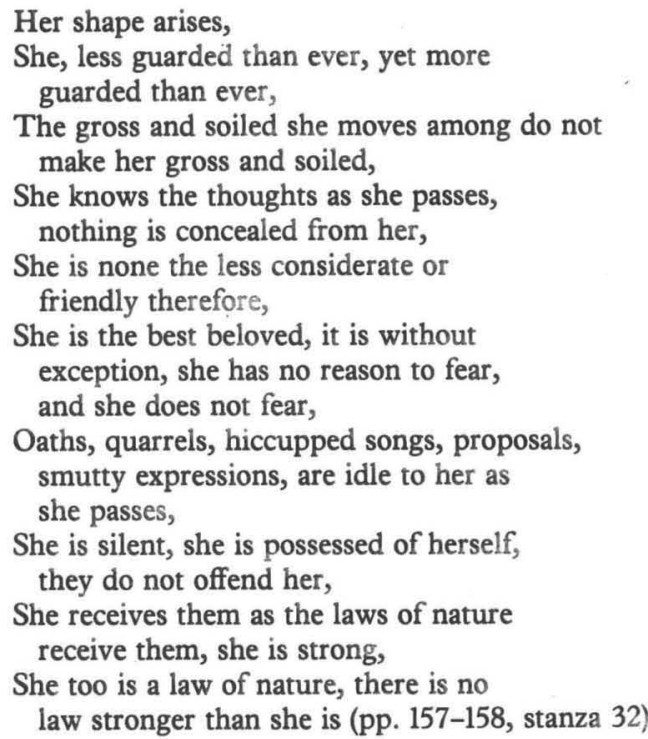

Our puzzlement over the kind of natural law that this idealized woman represents is cleared up when we turn to Whitman's notes and examine the entry that roughly corresponds to the last two lines of the stanza.

She received them / as the air received them / or as the laws of nature / receive them, / she too was a law in nature ... she was / as great as any ... / She was maternity. ${ }^{17}$

It is from Whitman's conception of maternity, then, that this portrait of exalted womanhood derived. Maternity for him is not only a source of strength, a state demanding homage and veneration but also a state of omniscience comparable to early infancy's conception of the Mother. 
Within the larger context of the poem, this idealized woman stands for America: The United States are fused in her. And since the poet elsewhere has related the States to maternity ("Poem of Many in One"18), we can assume that the reason he omitted that key word from the finished stanza of "Broad-Axe Poem" was to extend the symbolic ramifications of the woman. More specifically, taking into consideration that the next figure in the train is a man, we can conclude that Whitman meant the woman to be also the female version of the "strong being ... the proof of the race" that he announced in the discursive interlude, and that the man who follows her is the male counterpart of that being. ${ }^{19}$

But while the woman is an abstraction, the man whose shape arises next is not only realistic but also an exact daguerreotype of Walt Whitman himself. Like the poet, the man of "pure American breed" whose "shape" arises is "ample-limbed, a good feeder, weight a hundred and eighty pounds, full blooded, six feet high, forty inches round the breast and back, countenance sun-burnt, bearded. ..."

E. H. Miller finds in Whitman's self-portraiture elements of selfmockery. ${ }^{20} \mathrm{I}$ believe that from the sophisticated reader's point of view this minute self-description - particularly when it is meant as the model being of the "greatest city"-is positively funny, but I do not think that Whitman meant it that way. I rather think that this is simply a gesture both "arrogant" and "naive" on the poet's part, to use two of the attributes with which he ushers his own "shape" into the procession. And it must be this same combination of arrogance and naiveté that moves him to follow his physical description with the corroboration of his phrenology by listing fifteen of the forty-odd phrenological faculties in which he had been found highly endowed, "voluptuous, inhabitive, combative, conscientious. . .."21

Whitman's self-portrait diminishes the poem because it interferes with the rich suggestiveness of the central symbol; ${ }^{22}$ on the other hand, the selfportrait is very useful because it confirms the personal origins of the inspiration of the poem. The "shape" of Walt Whitman following the "shape" of maternity conveys a "grown-up" version of Nativity (I am using "nativity" here as meaning primarily the combined representation of mother and child) and brings the poem full circle to its beginning. Whitman, as he naively confessed in "Clef Poem," is psychologically still speaking at the "divine nipple" of his mother's breast. ${ }^{23}$ But from the cultural point of view, the significant difference, of course, is that the divine nipple has been transformed into a whole country. "Broad-Axe Poem" achieves in a most original way the fusion of Mother, Son and States that Whitman more explicitly, but less successfully, attempted in "Poem of Many in One."

In the shapes of the future-the "result of centuries" with which the procession (and the poem) ends - the shapes of "untamed young men" and of "women fit for These States" are again central. They populate "a hundred 
Free States, begetting another hundred North and South." Everybody and everything is ultimately fused into a universal symbiotic embrace: "shapes bracing the whole earth, and braced with the whole earth."

\section{Barnard College}

\section{NOTES}

1 "Broad-Axe Poem" was the original title of "Song of the Broad-Axe" when it first appeared in the second (1856) edition of Leaves of Grass. My discussion of the poem refers to its 1856 form. Consequently the page numbers in my citations are those of the second edition. But since the second edition is not easily accessible, I have also added the stanza numbering of the third edition, which basically maintains the forms of the 1856 poems and which is easily available in paperback (The Facsimile Edition of the 1860 Text of Leaves of Grass, ed. Roy Harvey Pearce [Ithaca: Cornell University Press, 1961]). I have followed the same procedure with "Poem of Many in One" and "Clef Poem," which enter my discussion briefly.

2 This particular stanza has been removed from post-1860 editions of the poem. The dropping of this stanza is actually the one major change between the first version of the poem in 1856 and the final form it assumed in 1867. Those interested in the detailed changes the poem underwent between its first and final forms should consult Leaves of Grass: A Textual Variorum of the Printed Poems, ed. Sculley Bradley, Harold W. Blodgett, Arthur Golden, William White (New York: New York University Press, 1980), 176-189.

3 See "The Psychoanalytic Play Technique: Its History and Significance," in New Directions in Psychoanalysis, p. 18. In the same book, in her essay "On Identification," p. 310, Klein also observes that she has found that "aggressive impulses and phantasies arising in the earliest relation to the mother's breast, such as sucking the breast dry and scooping it out, soon lead to further phantasies of entering the mother and robbing her of the contents of her body."

4 See Frederik Schyberg, Walt Whitman (New York: Columbia University Press, 1951), p. 135; James E. Miller, Jr., A Critical Guide to "Leaves of Grass"(Chicago: The University of Chicago Press, 1957), p. 91; Gay Wilson Allen, The New Walt Whitman Handbook (New York: New York University Press, 1975), p. 239. A study of this stanza was also made by Stanley Coffman in Explicator, 12 (April 1954), 39. More recently, Linda Peavy in her article, "Wooden Flesh and Metal Bone," Walt Whitman Review, 20 (December 1974), 152-154, suggests that certain irregularities in the trochaic meter make this stanza resemble (except for the rhyme) the double-barreled Anglo-Saxon line. She substantiates her unusual thesis by the fact that "the substance of Whitman's lines" resembles the "substance of Anglo-Saxon riddles," which describe but do not give the word.

5 Leaves of Grass, ed. by Oscar Lovell Triggs, 3:161. This volume is part of The Complete Writings of Walt Whitman, ed. R. M. Bucke, T. B. Harned, and H. L. Traubel.

6 The New Walt Whitman Handbook (New York: New York University Press, 1975), p. 240.

7 It is interesting to note that Whitman found another place in the poem to incorporate (with only slight revision) the discarded line about the rain. It appears at the beginning of the fourth stanza (third line) in combination with a sylvan hut and a woodpile supporting the axe.

8 Jean Catel has suggested that Whitman may have got the idea of the axe as a symbol for his poem from Alfred B. Street's "Song of the Axe," which appeared in Graham's Magazine, April 
1855. See "Rythme et langage dans la 1re Edition des Leaves of Grass"(Montpellier, France, 1930), pp. 74-75. This monograph is Catel's Thèse Complementaire to his Walt Whitman: La Naissance du Poète (Paris: Les Editions Rieder, 1929).

9 See Richard Maurice Bucke, ed., Notes and Fragments Left by Walt Whitman (London, Ontario, 1899), p. 33.

10 "Fenimore Cooper's Leatherstocking Novels" in Studies in Classic American Literature (New York: Doubleday Anchor Books, 1953), p. 73. I would like to add that, as a non-native American, I have been frequently struck by the fact that the word "aggressive" carries in this culture the positive connotations of the word "assertive."

11 An 1855-56 Notebook Toward the Second Edition of "Leaves of Grass" (Carbondale: Southern Illinois University Press, 1949), p. 17.

12 Quaker values were a felt presence in the Whitman household. The poet's parents, although not Quakers in the strict sense of the word, frequently attended Quaker meetings. More importantly, his maternal grandmother, Naomi Van Velsor, was before her marriage a member of the Long Island Quaker community. Walt Whitman's appreciation of the Quaker aspect of his background has been expressed in his frequently mentioning to his friends with pride that he was "partly of Quaker stock." (Quoted in Schyberg, p. 34.) Additional information about Whitman's Quaker influences can be found in the following texts: William Sloan Kennedy, "Quaker Traits of Walt Whitman," In Re Walt Whitman, ed. Traubel, Bucke, Harned (Philadelphia: David McKay, 1893), pp. 213-214; Howard Hintz, The Quaker Influences in American Literature (New York \& London: Fleming H. Revell, 1940), pp. 59-75; Henry Seidel Canby, Walt Whitman: An American (New York: Literary Classics, 1943), pp. 31-35.

13 That Whitman identified temperamentally more with his mother than with his father has been noted by several of his biographers. This is how one of them, and a close friend of Whitman's, put it:

He was his mother's child unmistakably . . . With all his rank masculinity, there was a curious feminine undertone in him which revealed itself ... in the gentleness of his touch and ways, the attraction he had for children and the common people. A lady in the West writing to me about him spoke of his "great Mother-Nature."

See John Burroughs, Walt Whitman: A Study (Boston: Houghton Mifflin, 1896), p. 49.

14 Whitman expressed such a stance early in articles that he wrote as a young journalist in the mid-1840s for The Brooklyn Daily Eagle. See "Women Should Possess Their Own," "Women," "Female Labor," in Cleveland Rodgers and John Black, eds., The Gathering of The Forces(London: Putnams, 1920) 1: 73, 87, 148.

15 For the use of "symbiosis" as an intrapsychic state of early infancy during which the child experiences itself in a state of fusion with its mother, see Margaret Mahler, The Psychological Birth of the Human Infant: Symbiosis and Individuation (New York: Basic Books, 1975), particularly pp. 43-44. Whitman's poetry frequently demonstrates a lasting imprint of this psychological state.

16 The suggestion that the "leap" of the axe connotes among other things "the leap over the Atlantic" was (as far as I know) first made by James E. Miller, Jr., in Critical Guide, p. 100.

17 See 1855-56 Notebook, p. 38.

18 "Have you possessed yourself with the spirit of the maternity of These States?" (p. 192, stanza 28). 
19 In this connection, see the following note, found on p. 11 of the 1855-56 Notebook: "Full poem-indicating any/way (loosely) the illustrations of the true female character." The note heads a list of attributes that correspond to those we find in the idealized woman of "Broad-Axe Poem." Whitman apparently gave up the idea of writing a separate poem on this topic, which found its place within the larger theme of nativity in "Broad-Axe Poem."

20 Walt Whitman's Poetry: A Psychological fourney (New York: New York University Press, 1968), p. 137.

21 By twentieth-century standards, phrenology is considered a popular pseudo-science of the 19 th century; in its own time, however, phrenology was taken seriously by many scientists and educated people. It professed that the mind is composed of independent faculties, which were localized in different regions of the brain. The degree of each person's endowment of each faculty could be determined by an examination of one's cranium. Whitman had a phrenological examination by Lorenzo Fowler in 1849 , which showed a high degree of endowment in most of the faculties. Whitman published his phrenological chart five times starting with an anonymous review he published in The Brooklyn Daily Times, on 29 September 1855. "Clef Poem" has, in fact, undergone considerable transformation since its first appearance. Reduced to half of its original length and retitled "On the Beach at Night Alone," it no longer allows us to see the symbiotic aspect of its original inspiration. Consult Leaves of Grass: A Textual Variorum for the step-by-step changes between the first and final form of this poem. 